\title{
SCARABÆUS HERCULES.
}

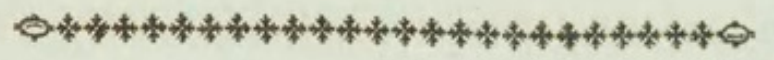

CHARACTER GENERICUS.

Antenna clavatæ capitulo fiffili.

Tibice anticæ fæpius dentatæ.

Lin. Syft. Nat. p. 541.

CHARACTER SPECIFICUS, EC.

SCARAB EUS fcutellatus, thoracis cornu incurvo maximo: fubtus barbato unidentato, capitis recurvato: fupra multidentato.

$$
\text { Lin. Syf. Nat. p. } 54^{1} \text {. }
$$

Röfel. Inf. 2 Scarab. 1. tab. A. fig. 1. et Inf. 4 . tab 5. fig. 3 .

Edw. Av. tab. 334.

Quis, ait celeberrimus Bufronus, efficit ut de fummo mundi Creatore altius fublimiufque concipiamus? an ille qui foles et planetas poteftate fua formantem, mundorumque circulos gubernantem depingit; an qui apum œconomiam ordinantem, aut alas Scarabæi ferio et fedulo plicantem? Talis equidem tanti viri fententia Hiftoriæ Naturalis minutiores partes inveftigantibus foret inimiciffima, utpote vix hominis literati ftudio dignas, 
dignas, aut faltem pra majoribus et nobilioribus Zoologiæ partibus fordidas, nifi quod et alii de hac re cenfuerint in eadem ponamus trutina; viri nempe non minus ingenio vivido et pollenti, quam virtute per omne ævum laudandi. Perilluftris Boylius breviter et nervofe fuam ita fententiam edidit; fe non tam Naturæ majoribus horologiis, quam parvulis et minutis ftupefcere; Deumque plane dixit effe maximum in minimis. Et profecto fi elephantis aut rhinocerotis molem giganteam miramur, acarum attoniti contemplemur neceffe eft, cui plura funt membra, corpufque magis complicatum quam animalibus majoribus. Ad fummum vero augetur nobis admiratio, innumera ifta animalcula explorantibus, qua non nifi microfcopii ope videnda funt; quibus vel ipfe acarus eft quafi elephas. Immortalis PLINIr fententia de his parvulis Naturæ operibus ex ipfius verbis conftat. "In his tam parvis, tamque fere nullis, quæ ratio! quanta vis! quam inextricabilis perfectio!"

Infectum vero, quod nunc defcribere pergimus, nequaquam ad minora infecta pertinet, fed inter maximas fui generis fpecies numeratur. Phyficis probe cognitum eft, et a multis defcriptum. Americam incolit calidiorem, et inter alios fcarabæos præminet cornu in vaftam longitudem e thorace extenfo necnon alio cornu a capite orto, et furfum tendente, donec cornu thoracis pene occurfet. Cornu fuperius fuperficiem habet inferiorem villo, feu tomento denfo holoferico elegantiffime veftitam. Infecta hæc (ut fertur) Mammæx Americanæ ramulos cornubus complexa, circum-gyrando vulnerant, ut humorem ab arbore incifa ftillantem 
ftillantem forbeant; quo mox inebriata in terram decidunt, et facillime capiuntur. Huic tamen famæ, ut doctus obfervat $\mathrm{F}_{\triangle B}$ R Icius, fides non temere habenda eft, quoniam, ut antea diximus, cornu, cui fuperficies inferior barbata eft, hoc modo abrafum omnino denudaretur. Infectum hoc, ob molem infignem, optimum præbet exemplum characteris generici. Magnitudine multum variat. Dubitari etiam merito poteft, annon minora aliqua fpecimina veluti fpeciem diverfam defcripferint auctores; exempli gratia Scarabæum Alcidem $F_{A B R I C I I}$, adeo huic noftro affinem, at vix probe feparari queat, quamvis multo fit minor, cornuaque minus confpicue dentata gerat. 





है 


\section{HER C U L E B E E T LE,}

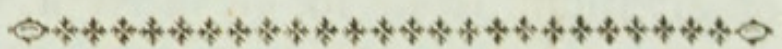

\section{GENERIC CHARACTER.}

Antenne divided at the tip or head into feveral lamellæ.

Tibia, (or fecond joints of the fore legs) generally toothed.

\section{SPECIFIC CHARACTER, छ'C.}

BEETLE, with the thoracic horn very large, ben: downward, bearded beneath, furnifhed with a fingle tooth, and bifid at its extremity: the horn on the head bent upwards, and furnifhed on its upper part with feveral teeth.

Röfel. vol. 2. plate A. fig. 1. and vol. 4. plate 5. fig. 3 .

Drury, vol. 1. plate 30. fig. 1.

Edwards, vol. 7. plate 324 .

Who, fays the celebrated Count De Buffon, gives us the grandeft and, and moft magnificent ideas of the Creator of the univerfe? He who reprefents him fuperintending the formation of funs and of planets, 
and guiding the revolutions of worlds, or he who difcovers him bufied in regulating the oeconomy of an hive of bees, or deeply engaged in foiding the wings of a beetle? Such an obfervation, from fo elevated a character, might be capable of exciting a very wrong and unfavourable idea, with refpect to the ftudy of the fmaller branches of Natural Hiftory; as if unworthy of any confiderable thare of attention, or at leaft of but flight importance, when compared with the higher orders of Zoology. But let us recollect the fentiments of other men, of the moft comprehenfive minds, the moft brilliant abilities, and the moft exalted piety and virtue.

The celebrated Mr. Boyle ufed to exprefs himfelf on this fubject in a fomewhat fingular phrafe, viz. That for his own part, his wonder dwelt not fo much on the clocks as the watches of Nature; and that the Creator appeared in reality to be maximus in minimus. If we are fruck with admiration at the prodigious bulk of the elephant, or the rhinoceros, we are loft in aftonifhment at the contemplation of a mite, for in that animal there is a more complicated ftructure, and a greater variety of parts than in the larger animals; and how muft this aftonifhment increafe, when we contemplate by the help of glaffes, thofe innumerable legions of animalcula, compared to which, a mite may itfelf be regarded as a kind of elephant.

The opinion of Plivy on the minuter parts of $\mathrm{Na}$ ture is evident, from his own words. "In his tam parvis tamque fere nullis quæ ratio! quanta vis! quam inextricabilis perfectio!".

The 
The infect, however, which makes its appearance on the prefent plate, is not amongft thofe of the fmaller order; but on the contrary, is one of the mort gigantic animals of the clafs to which it belongs. This curious creature has long been known to the admirers of $\mathrm{Na}$ tural Hiftory, and has been figured by feveral authors. It is a native of the warmer parts of America, and is remarkable for the exceffive length of the horn, which proceeds from its thorax, as well as for another horn which proceeds from its head, and bends upwards, fo as almoft to meet the thoracic one. The uppermoft of thefe horns, or proceffes, is moft curioufly coated on the inner furface, with a fine hair or velvet-like fubftance.

It has been faid that thefe infects have a cuftom of taking hold of the flender branches of the Mammæa Americana, and fwinging themfelves round with fuch rapidity, as to wound, by this circular motion, the branch on which they faften, in order to be enabled to fuck the juice diftilling from the tree; by which they are foon inebriated, fo as to fall in great numbers on the ground, and to be eafily taken. But this account, as the learned FABRICIUs has well obferved, feems not very probable; fince the thoracic horn being bearded on its lower furface, would undoubtedly be made bare by this operation. This Infect, from the remarkable fize of all its parts, affords an admirable example of the characters of the genus to which it belongs.

It varies much in fize, and it may even be much doubted whether fome of the fmaller fpecimens have not been regarded as diftinct fpecies by authors: fuch, for inftance, is the Scarabous Alcides of FABricius, 
which feems fo extremely nearly allied to the Hercules, as fcarce to admit of feparation, notwithftanding its fize, which is hardly more than half that of the former; and the horns not furnifhed with fuch remarkable denticulations as in the Hercules. 


\section{$2 \mathrm{BHL}$ Biodiversity Heritage Library}

Shaw, George. 1790. "The Hercules Beetle, Scarabæus hercules [PI. 34]." The Naturalist's Miscellany 1(XI), https://doi.org/10.5962/p.310686.

View This Item Online: https://www.biodiversitylibrary.org/item/281460

DOI: https://doi.org/10.5962/p.310686

Permalink: https://www.biodiversitylibrary.org/partpdf/310686

\section{Holding Institution}

Museums Victoria

\section{Sponsored by}

Atlas of Living Australia

\section{Copyright \& Reuse}

Copyright Status: Public domain. The BHL considers that this work is no longer under copyright protection.

This document was created from content at the Biodiversity Heritage Library, the world's largest open access digital library for biodiversity literature and archives. Visit BHL at https://www.biodiversitylibrary.org. 